\title{
Comparison of lipid, otolith and morphometric condition indices of pelagic juvenile cod Gadus morhua from the Canadian Atlantic
}

\author{
Iain M. Suthers ${ }^{1, *}$, Angus Fraser ${ }^{2}$, Kenneth T. Frank ${ }^{2}$ \\ ${ }^{1}$ Dept. of Biology, Dalhousie University, Halifax, Nova Scotia, Canada B3H 4J1 \\ ${ }^{2}$ Marine Fish Division, Bedford Institute of Oceanography, Dartmouth, Nova Scotia, Canada B2Y 4A2
}

\begin{abstract}
Body condition indices were assessed for pelagic juvenile cod (14 to $31 \mathrm{~mm}$ standard length, SL) over 2 cruises in spring 1987 in Canadian Atlantic waters on the southern Scotian Shelf. Three different indices determined from the residuals of univariate regressions were (1) triacylglycerol (TAG) content on standard length (SL), (2) dry body weight on $\mathrm{SL}_{\text {, }}$ and (3) back-calculated change in SL from the peripheral 14 daily growth increments of the otolith on SL; hereafter referred to as TAGSL, DWTSL, and OTOSL respectively. Correlations between indices declined from TAGSL:DWTSL 10.69 , 0.64 , cruises $87-1$ and $87-2$ respectively), to TAGSL:OTOSL $(0.38,-0.05)$, to DWTSL:OTOSL $(0.05$, 0.03 ), a surprisingly low correlation considering that the indices were derived from the same individual. This pattern was also demonstrated by a principal component analysis (PCA), showing that after the first (size) component, otolith-based growth alone loaded on PC 2, then TAG contrasted with SL loaded on PC 3, and dry body weight showed the highest correlation with the starvation-independent SL. Supplementary analyses from 4 other cruises during 1985 and 1986 confirmed the weak correlation between DWTSL, OTOSL and other morphometric measures. All indices were positively correlated with zooplankton biomass, but of the 16 separate cruise by index comparisons, only 6 were significantly correlated with zooplankton, of which 3 were the OTOSL. The rapid somatic/otolith growth of pelagic juvenile cod may respond rapidly to prey abundance, and rapid growth may preclude accumulation of lipids (TAG), indicating that the utility of a condition index will depend on the species and life stage examined. Indices of recent otolith growth appear good measures of pelagic juvenile cod condition.
\end{abstract}

\section{INTRODUCTION}

Spatial variation in condition indices of larval fish can indicate linkages between environmental variables, growth and probable survival (e.g. Koslow et al. 1985 , Theilacker 1986, Buckley \& Lough 1987, Suthers et al. 1989). Condition indices may also be used to prorate larval abundance by the proportion of starving larvae (Frank \& McRuer 1989), and provide a superior means of predicting inter-annual variation in recruitment assuming that condition and survival probability are correlated (Anderson 1988). Given the temporal persistence in individual growth and relative size throughout the early life stages (Chambers et al. 1988), the comparison of condition between stocks or water masses is an exciting development. Therefore estima-

\footnotetext{
- Present address; School of Biological Science, University of New South Wales, Kensington, NSW 2033, Australia
}

tion of condition indices and explanation of their variance is becoming increasingly attractive due to the difficulties associated with estimating larval mortality in the ocean (Taggart \& Leggett 1987a, b).

Morphometric condition indices are derived by measuring a variable that is responsive to the larva's feeding environment, such as dry weight or anal body depth, which is then adjusted by a starvationindependent variable (e.g. standard length) to remove the effect of variable body size. There has been a recent proliferation of condition indices other than morphometric ones including; biochemical indices (RNA:DNA; review in Buckley 1984), lipids (Fraser 1989), recent growth indices using the outer daily growth increments of the otolith (Methot 1981, Suthers et al. 1989, Hovenkamp 1990), and histological indices that involve scoring the appearance of certain tissues (Ehrlich 1974, Theilacker 1978, 1986, O'Connell \& Paloma 1981, Martin et al. 1984, Theilacker \& 
Watanabe 1989). Only a few studies have attempted to intercalibrate different indices (Theilacker 1978, 1986, Martin et al. 1984, Martin \& Wright 1987), but condition indices are difficult to compare within the same individual. In addition, it is possible that variation of indices within an individual may be as great as variation between individuals, or between samples.

Comparison of several different indices is advisable. This screening should indicate which is the best index as well as increase confidence in the assessment of condition, particularly in the absence of laboratory validation. Some laboratory studies have attempted to calibrate condition indices with the rearing environment (Ehrlich 1975, Theilacker 1978, 1986, McGurk 1985a, Martin \& Wright 1987, Håkanson 1989a), but the morphometry and lipid content of reared larvae is frequently quite different from larvae in the wild due to container size (Theilacker 1980), prey density and quality (Håkanson 1989a), and collection technique (Blaxter 1971, Theilacker 1986, McGurk 1985b). Intercalibrating several indices from wild larvae would obviate difficulties associated with the application of laboratory studies to the fleld. Such a comparison may be confounded by possible varying rates of decline and recovery of the various indices within an individual (Martin \& Wright 1987), and without further study one must assume that the various indices fluctuate similarly.

In this paper we test the hypothesis that 3 different indices of condition (morphometric, otolith- and lipid- based), derived from the same individual, are positively correlated. The lipid index involves estimating the content of triacylglycerol (TAG, a 'storage lipid'), standardised for size by either cholesterol content (Fraser 1989) or length (Håkanson 1989a). TAG reserves have been shown to be dependent on the nutritional state of herring larvae (Fraser 1989), while cholesterol remains essentially unchanged during starvation (Håkanson 1989a).

Pelagic juvenile cod collected off southwestern Nova Scotia were used to evaluate the above assumption. Previous studies on cod in this region revealed significant spatial heterogeneity in growth that was explained by zooplankton biomass (Suthers et al. 1989). Ancillary data from 1985 and 1986 were used to determine the correlation structure among various morphometric and otolith indices. Finally, we determined the magnitude of the correlations between the various condition indices and zooplankton biomass

\section{MATERIAL AND METHODS}

Cruises and sampling gear. Pelagic jurenile cod collected from 2 cruises conducted off southwestern Nova Scotia during May and early June of 1987 (cruises 87-1, 87-2; Table 1) were used to generate data for each of the 3 indices. Additional morphometric and otolith indices were compared among larvae sampled on 5 cruises in May and June of 1985 and 1986 (Table 1). The

Table 1. Summary information on cruise date, gear, condition indices, and sample size (N) of pelagic juvenile cod sampled off southwestern Nova Scotia with a Tucker trawl (except where noted), and type of analysis used. ABD: anal body depth; PBD pectoral body depth; DWT: dry weight; EYED: eye diameter; OTO: peripheral $14 \mathrm{~d}$ otolith increment widths; TAG: triacylglycerol. Treatment of larvae: $\mathrm{N}_{2}$, liquid nitrogen; f, $5 \%$ formalin; e, transferred to $95 \%$ ethanol. Analysis: reg, residuals from univariate regression on $\mathrm{SL}_{\text {; }}$ PCA, principle components analysis

\begin{tabular}{|c|c|c|c|c|c|c|c|}
\hline $\begin{array}{l}\text { Year- } \\
\text { Cruise }\end{array}$ & Dates & $\begin{array}{c}\mathrm{N} \\
\operatorname{stns}\end{array}$ & $\begin{array}{c}\text { Range in } \\
\text { bathymetry }(\mathrm{m})\end{array}$ & $\underset{\text { larvae }}{\mathrm{N}}$ & $\begin{array}{l}\text { Treat- } \\
\text { ment }\end{array}$ & Indices & Analysis \\
\hline $87-1^{\alpha, b}$ & 9-18 May & $\begin{array}{r}10 \\
8 \\
23\end{array}$ & $\begin{array}{l}30-150 \\
30-110 \\
30-180\end{array}$ & $\begin{array}{r}44 \\
32 \\
148\end{array}$ & $\begin{array}{l}\mathrm{N}_{2} \\
\mathrm{~N}_{2} \\
\mathrm{f}, \mathrm{e}\end{array}$ & $\begin{array}{l}\text { TAG, OTO, DWT } \\
\text { TAG } \\
\text { DWT, ABD }\end{array}$ & $\begin{array}{l}\text { reg, PCA } \\
\text { reg } \\
\text { reg }\end{array}$ \\
\hline $87-2$ & 28 May-4 June & $\begin{array}{l}31 \\
40\end{array}$ & $\begin{array}{l}42-194 \\
42-194\end{array}$ & $\begin{array}{r}31 \\
146\end{array}$ & $\begin{array}{l}\mathrm{N}_{2} \\
\mathrm{~N}_{2}\end{array}$ & $\begin{array}{l}\text { TAG, OTO, DWT } \\
\text { TAG, ABDC }\end{array}$ & $\begin{array}{l}\text { reg, PCA } \\
\text { reg }\end{array}$ \\
\hline $86-1$ & 10-18 May & 21 & $32-192$ & 136 & $f, e$ & $\mathrm{OTO}^{d}, \mathrm{ABD}$ & reg \\
\hline $86-2^{b, e}$ & 14-23 May & $\begin{array}{r}23 \\
5\end{array}$ & $\begin{array}{l}32-192 \\
32-1.92\end{array}$ & $\begin{array}{l}158 \\
124\end{array}$ & $f_{1} e$ & $\begin{array}{l}\text { DWT, ABD } \\
\text { DWT, ABD }\end{array}$ & $\begin{array}{l}\text { reg } \\
\text { reg }\end{array}$ \\
\hline $86-3$ & 5-11 June & 40 & $22-159$ & 177 & $f, e$ & $D W T, A B D$ & reg \\
\hline $85-1,85-2^{d, b}$ & $\begin{array}{l}\text { 9-21 May, } \\
\text { 16-22 May }\end{array}$ & 32 & $20-140$ & 139 & $f_{1} e$ & $\begin{array}{l}\text { OTO, DWT, ABD, } \\
\text { PBD, HL, EYED }\end{array}$ & reg, PCA \\
\hline \multicolumn{8}{|c|}{$\begin{array}{l}\text { "1.0 m diameter ring net, } 1.0 \mathrm{~mm} \text { mesh } \\
\text { Cruise does not include main spawning ground, Browns Bank } \\
\text { ABD and SL measured fresh before frevzing } \\
\text { 'OTO includes } 3 \text { nearshore stations from cruise } 86-2 \\
\text { "Zooplankton biomass not measured }\end{array}$} \\
\hline
\end{tabular}


cruises extended from Browns Bank $\left(42.75^{\circ} \mathrm{N}, 66.25^{\circ}\right.$ $W$ ), the main cod spawning ground, to approximately $200 \mathrm{~km}$ north (except during cruises 87-1, 86-2, and 85-2 which did not include Browns Bank, and covered only the nearshore waters; Table 1). The sampling gear was either a Tucker trawl ( $2 \mathrm{~m}^{2}$ effective mouth opening, 1.6 $\mathrm{mm}$ mesh), or a $1.0 \mathrm{~m}$ diameter ring net $(1.0 \mathrm{~mm}$ mesh; Table 1). The gear was generally towed from $40 \mathrm{~m}$ depth to the surface for approximately 30 min at 3 knots. Zooplankton biomass (sampled with $333 \mu \mathrm{m}$ or $405 \mu \mathrm{m}$ mesh nets) was expressed as dry weight $\left(\mathrm{mg} \mathrm{m}^{-3}\right)$. Further details are provided in Suthers \& Frank (1989, 1990) and Suthers et al. (1989).

Lipid-otolith-dry weight condition index. During cruises 87-1 and 87-2 individual cod were placed in glass vials and frozen in liquid nitrogen within $30 \mathrm{~min}$ after completion of the tow ( $n=42, n=31$ respectively). The vials were later transferred to a $-70^{\circ} \mathrm{C}$ freezer until analysis 24 mo later. Three lipid classes were quantified with the Iatroscan thin layer chromatography-flame ionisation detection system, and calibration curves were prepared from a composite standard (Fraser et al. 1987). The larvae were thawed, measured (standard length, SL to the nearest $0.5 \mathrm{~mm}$ ), freeze-dried for $24 \mathrm{~h}$ and weighed to the nearest $0.1 \mathrm{mg}$ (dry weight, DWT). As the otoliths were also required, the heads were cut off (the body temporarily re-frozen in liquid nitrogen), and passively extracted in 2:1 dichloromethane and methanol for $12 \mathrm{~h}$. Further soaking of the head for another $36 \mathrm{~h}$ yielded no further lipid. The head extract was then added to the body, ground in the dichloromethane and methanol solvent, with $\mathrm{KCl}$ solution, and centrifuged for 10 min. Neutral lipid in the supernatant was evaporated, and re-dissolved in $75 \mu \mathrm{l}$ of solvent and dotted onto silica-coated chromatography rods. TAG, cholesterol and free fatty acids (FFA), and nonadecane as the internal standard were separated in hexane:diethyl ether:formic acid (82.4:2.5:0.045 volumetric, $30 \mathrm{~min}$, and 55.2:29.7:0.075 volumetric $25 \mathrm{~min})$. Rods were air-dried in a desiccator and analysed with an Iatroscan. The FFA fraction is indicative of polar lipid breakdown, and was always $<5 \%$ of neutral lipid. All the lapillar otoliths were extracted and analysed as outlined below, with otoliths from $11 \%$ of the 88 lipid-extracted fish discarded due to poor clarity of daily growth increments.

Otolith and other morphometric analysis. Cod not frozen for lipids on cruise 87-1 were preserved in $5 \%$ formalin and transferred to $95 \%$ ethanol (Table 1), measured for SL, anal body depth (ABD; after Koslow et al. 1985) and later oven-dried to a constant weight as described below. A subsample from cruise 87-2 were measured before freezing for SL and ABD (Table 1).

Pelagic juvenile cod from other cruises were not lipid-extracted (Table 1) and were preserved in $5 \%$ buffered formalin in freshwater, and in all but one comparison were transferred to $95 \%$ ethanol in 5 to 14 d. SL $( \pm 0.5 \mathrm{~mm})$, and ABD (measured with an ocular micrometer, $\pm 0.04 \mathrm{~mm}$ ) were recorded, and cod were oven-dried at $60^{\circ} \mathrm{C}$ for $48 \mathrm{~h}$, cooled in a desiccator, and weighed $( \pm 0.1 \mathrm{mg})$. For cruise 85-1,2 only, the following measurements were also made to a resolution of $\pm 0.04 \mathrm{~mm}$; pectoral body depth (PBD), eye diameter (EYED), and head length (HL), after Koslow et al. (1985). The otoliths were then extracted in water under polarised light, mounted onto glass slides with fastdrying cement, and ground with $3 \mu \mathrm{m}$ lapping film to the nuclear plane. The outer 14 daily growth increments and otolith radius were measured using an image analysis system (Campana 1987). These growth increments were assumed to be a conservative index of recent growth, reflecting the environmental conditions at capture. Similar results were found using the width of the outer 7 increments.

Analyses. The otolith index of recent growth (Suthers et al. 1989) was used to back-calculate SL $14 \mathrm{~d}$ prior to capture, using the biological intercept (BI) method (Campana 1990):

$$
\begin{aligned}
& \mathrm{SL}_{\mathrm{C}-14 \mathrm{~d}}=\mathrm{SL}_{\mathrm{C}}+ \\
& \quad\left[\left(- \text { width outer } 14 \text { increments) }\left(\mathrm{SL}_{\mathrm{C}}-\mathrm{SL}_{0}\right) / \text { radius }\right]\right.
\end{aligned}
$$

where $\mathrm{SL}_{C}$ was SL at capture; $\mathrm{SL}_{0}$ was the length at hatch $=4.5 \mathrm{~mm}$ (Fahay 1983); and radius was the distance from the hatch check to the periphery. The change in SL over $14 \mathrm{~d}$ was then used as the index in recent growth (termed OTO), similar to the otolith index of recent growth previously used by Suthers et al. (1989). No measurements were corrected for preservation shrinkage as the bones are well ossified after metamorphosis to the pelagic juvenile stage. For example, cod $>14 \mathrm{~mm}$ SL decreased in SL $<5 \%$ after transferral from $5 \%$ formalin to ethanol, and by $4 \%$ from fresh to thawed SL (unpubl. data). Condition indices were generated as residuals of univariate regressions of TAG, DWT, OTO and ABD on SL using ordinary least square regressions. All variables (except $\mathrm{ABD}$ on SL) were log-transformed, which generated linear relationships and normally distributed residuals.

Comparison of the univariate residuals were of interest in this study since the measurements are labourintensive and only 1 or 2 variables are often recorded. However residual-based morphometric indices have been criticised for being confounded with body-size, and containing slightly different shape components (McGurk 1985a). These limitations may be overcome with a principle component ( $\mathrm{PC}$ ) analysis of $>3$ variables, and discarding the first (size) component (McGurk 1985a, Somers 1986). Therefore PC scores were calculated to compare with the univariate residuals for cruises 87-1,87-2, and 85-1,2. 

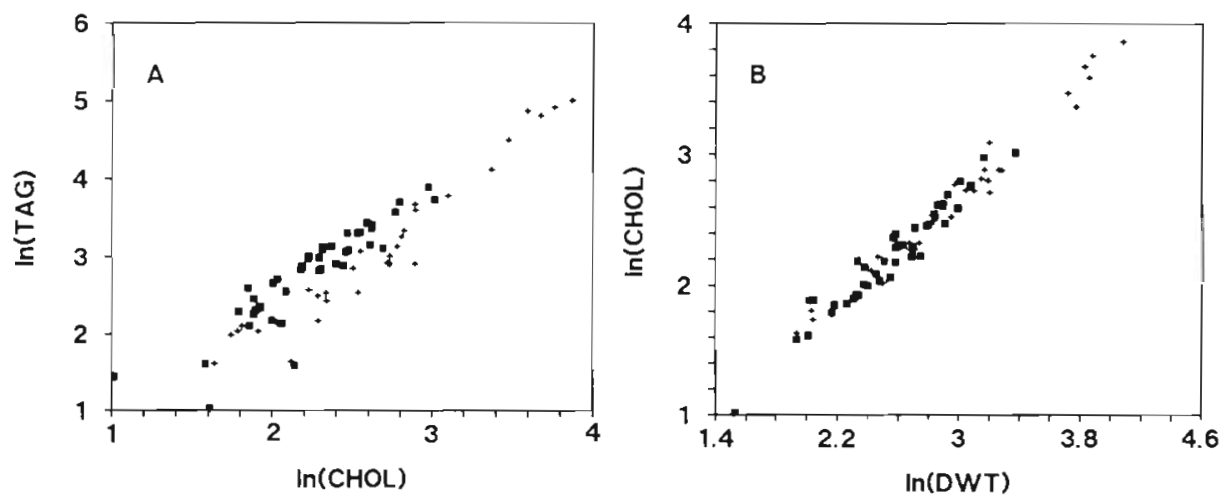

Fig. 1. (A) Relationship between triacylglycerol (TAG, x $10^{-5} \mathrm{~g}$ ) and cholesterol (CHOL, $\times 10^{-5}$ g) and (B) cholesterol and dry weight (DWT, mg). All variables were transformed by natural logarithms. (*) Cruise $87-1 ;(*)$ cruise $87-2$

\section{RESULTS}

\section{Correlation of TAG, DWT and OTO}

TAG content was linearly related to cholesterol (Fig. 1A; cruise 87-1, TAG $=-0.44+1.44 \mathrm{CHOL}, \mathrm{r}^{2}=0.81$; Cruise 87-2, TAG $\left.=-1.04+1.55 \mathrm{CHOL}, \mathrm{r}^{2}=0.94\right)$ and cholesterol was highly correlated with DWT (Fig. 1B; CHOL $=-0.443+1.04 \mathrm{DWT}, \mathrm{r}^{2}=0.93$ with no significant different between cruises; ANCOVA, $p>0.10$ ). However, the starvation-independent lipid variable, cholesterol, co-varied with TAG, such that a TAG: CHOL ratio, or residuals from a TAG:CHOL regression, would be confounded (shown by the significant correlation of the residuals between TAG on SL and CHOL on $\mathrm{SL}, \mathrm{r}=0.72,0.85$, cruises $87-1,87-2$ respectively). Therefore all starvation-dependent variables were regressed on $\mathrm{SL}$, to generate the residual condition indices

Log-log regressions for TAG, DWT and OTO on SL resulted in linear relationships (Fig. 2) and residuals that were normally distributed for all 3 indices (Fig. 3). Separate regressions were used for each cruise as TAG and OTO had significantly different intercepts although the slopes were not significantly different (ANCOVA, $p<<0.05$; Fig. 2, Table 2).

Nearly all incices over all cruises were positively related, although some indices were not significantly correlated. The lipid index (TAGSL) was significantly correlated with the dry weight index (DWTSL) on both cruises (Fig. 4A). TAGSL was significantly correlated with OTOSL only on cruise $87-1$ (Fig. 4B), while OTOSL was not significantly correlated with DWTSL in either cruise (Fig. 4C)

\section{Correlation with zooplankton and other indices}

The coefficients of total zooplankton biomass, as a co-variate with SL in a multiple regression model, were all positive, and were significant for OTO on cruises
86-3, 86-1,2, and 85-1,2 (Table 2; as determined in Suthers et al. 1989). Zooplankton biomass was also a significant covariate for TAG and ABD on cruise 87-1 (which was heavily influenced by 2 stations), and for DWT on cruise 85-1,2 (Table 2).
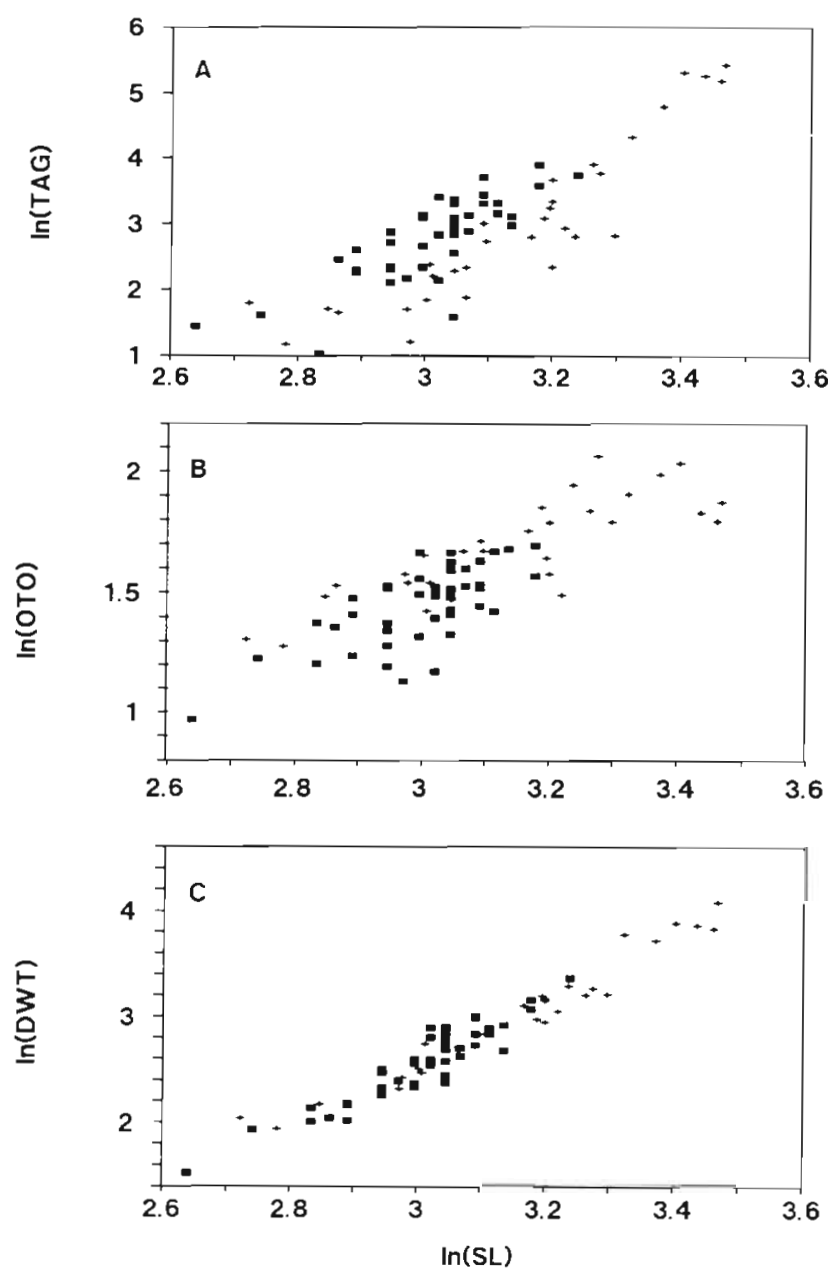

Fig. 2. (A) Relationship between TAG (triacylglycerol, x $10^{-5} \mathrm{~g}$ ) and SL (standard length, $\mathrm{mm}$ ), (B) OTO (change in SL over 14 d prior to capture, $\mathrm{mm}$ ) and SL, and (C) DWT (dry weight, mg) and SL. All variables were transformed by natural loganthms (•) Cruise $87-1 ;(*)$ cruise $87-2$ 

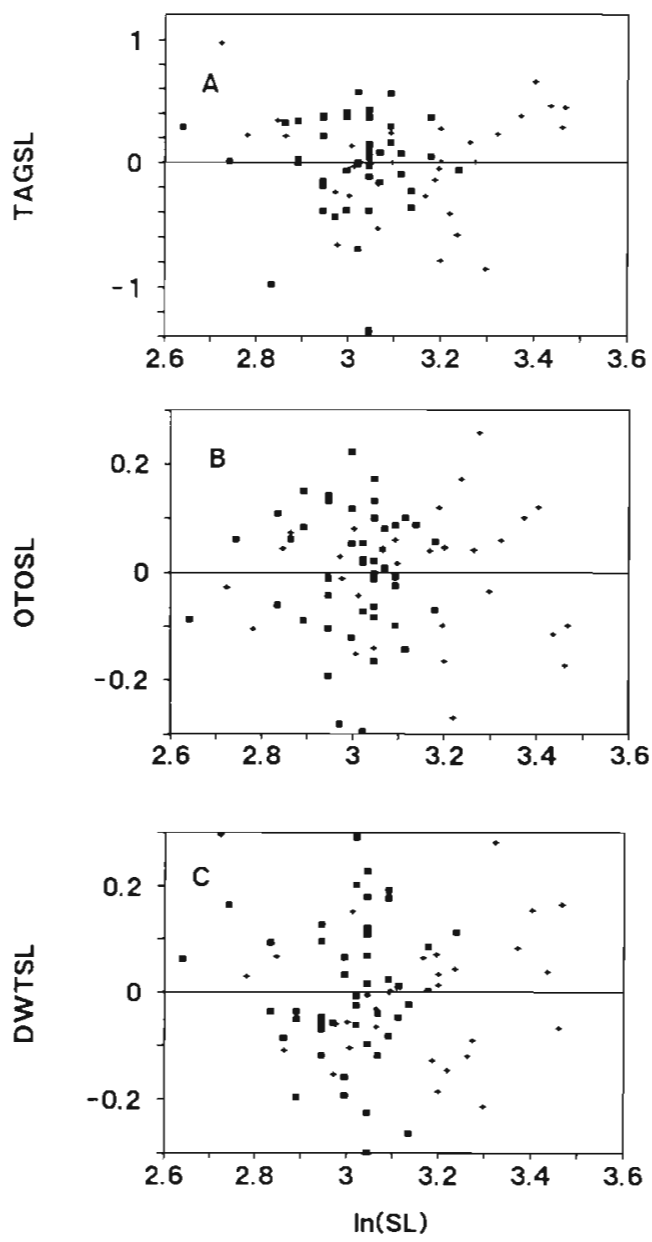

Fig. 3. Residual plots of (A) TAGSL, (B) OTOSL and (C) DWTSL on $\log (\mathrm{SL})$. (•) Cruise 87-1;() cruise 87-2

In general, a higher correlation was found between the 2 morphometric indices (DWTSL, ABDSL), than between the 3 different types of index; morphometric, otolith and lipid (Table 3).

\section{Principal component analyses}

Separate PCAs on OTO, TAG, CHOL, DWT and SL for cruises 87-1 and 87-2 showed that OTO varied differently relative to the other variables (Table 4, Fig. $5 \mathrm{~A}$ ). The first component loaded highly with all variables (the size component), explaining $>85 \%$ of the total variance, because most of the variation in the data set is due to size. Thus PC1 is analogous to using SL in generating residuals, which explained 50 to $98 \%$ of the regression variance in TAG, OTO and DWT (Table 2). The remaining components contain information on shape due to starvation.

PC2 was a contrast between OTO and all other variables, while PC3 contrasted TAG with SL (Fig. 5A).
DWT and CHOL loaded slightly on both axes, indicating little remaining variation after the size component was removed. The remaining components constituted $<2 \%$ of the total variance. The component scores of PC2 and PC3 correlated highly with the condition indices OTOSL and TAGSL respectively ( $\mathrm{r}>0.9$ ), thus showing that residual-based indices based on one variable provided similar information as a multivariate analysis of many variables.

For cruise 85-1,2 PC1 was the size component (92\% of total variance), and $\mathrm{PC} 2$ also contrasted OTO with all other variables. The third component contrasted the starvation-dependent variables $\mathrm{PBD}, \mathrm{ABD}$ and $\mathrm{DWT}$ with the starvation-independent variables EYED, HL, and SL (Fig. 5B). The remaining variables constituted less than $2 \%$ of the variance, although PC4 was a contrast between EYED and $\mathrm{HL}_{1}$ a result found in other morphometric studies (Ehrlich et al. 1976, McGurk 1985a). Similarly, the component scores of PC2 and PC3 correlated highly with OTOSL $(\mathrm{r}=0.93)$ and ABDSL ( $\mathrm{r}=0.62$ ) respectively.

\section{DISCUSSION}

The generally low correlation between all condition indices is surprising, considering that the indices were derived from the same individual, and that each of the indices were standardised by the same variable (SL). The low correlations were consistent over 3 yr from a variety of cruises and preservation procedures. The principal component analyses showed that the otolith condition index was relatively independent of the lipid and morphometric indices, and it was the otolith condition index that generally showed the highest correlation with zooplankton biomass. The rapid somatic/ otolith growth of pelagic juvenile cod may respond rapidly to prey abundance, and precludes accumulation of lipids (TAG). It appears that at least during this stage of the life cycle, TAG is an inappropriate index for pelagic juvenile cod.

\section{TAG condition indices}

The TAG index was positively correlated with morphometric variables, but poorly correlated with OTO and zooplankton abundance. However the TAG index has been used to diagnose starvation in plaice larvae (Ehrlich 1974), to evaluate nutrient and pollutant stress in herring, crab and lobster larvae (Fraser 1989), and to relate larval condition to prey abundance in anchovy larvae (Håkanson 1989b). Also, an index of total fatty acid levels in striped bass larvae also showed a precipitous drop after 2 d starvation (Martin et al. 1984). 
Table 2. Regression equations of the log-transformed variables (except ABD on SL) for deriving the condition indices of pelagic juvenile cod in (a) 1.987 for 3 indices, (b) 1987 for only TAG and fresh ABD, and (c) standard preservation in $5 \%$ formalin and transferral to $95 \%$ ethanol, $1985-1987$ cruises. Range in zooplankton in $\mathrm{mg} \mathrm{m}^{-3}$ 'Zoopl. p' refers to the significance level of log zooplankton biomass as another co-variate with SL in the regression model, in further explaining variance in TAG, OTO, DWT, and $\mathrm{ABD} \cdot \cdot \mathrm{p}<0.05$

\begin{tabular}{|c|c|c|c|c|c|c|c|}
\hline \multicolumn{2}{|c|}{ Cruise } & \multicolumn{2}{|c|}{ Regression equation } & \multirow{2}{*}{$\begin{array}{c}\text { N larvae } \\
44\end{array}$} & \multirow{2}{*}{$\begin{array}{c}\mathrm{r}^{2} \\
0.62\end{array}$} & \multirow{2}{*}{$\begin{array}{c}\begin{array}{c}\text { Range in } \\
\text { zooplankton }\end{array} \\
1-44\end{array}$} & \multirow{2}{*}{$\begin{array}{l}\text { Zoopl. p } \\
<0.001^{\text {. }}\end{array}$} \\
\hline (a) & $87-1$ & TAG & $=-10.47+4.40 \mathrm{SL}$ & & & & \\
\hline & $87-2$ & TAG & $=-11.42+4.61 \mathrm{SL}$ & 31 & 0.82 & $0-111$ & 0.54 \\
\hline & $87-1$ & OTO & $=-1.78+1.08 \mathrm{SL}$ & 45 & 0.50 & $1-44$ & 0.67 \\
\hline & $87-2$ & OTO & $=-1.01+0.86 \mathrm{SL}$ & 31 & 0.68 & $0-111$ & 0.17 \\
\hline & $87-1$ & DWT & $=-6.43+2.99 \mathrm{SL}$ & 47 & 0.87 & $1-44$ & 0.08 \\
\hline & $87-2$ & DWT & $=-6.22+2.92 \mathrm{SL}$ & 31 & 0.95 & $0-111$ & 0.26 \\
\hline (b) & $87-1$ & TAG & $=-7.75+3.57 \mathrm{SL}$ & 32 & 0.79 & $1-26$ & $0.03^{\prime}$ \\
\hline & $87-2$ & TAG & $=-8.32+3.76 \mathrm{SL}$ & 146 & 0.80 & $0-111$ & 0.38 \\
\hline & $87-2$ & $A B D^{a}$ & $=\quad 0.10+0.16 \mathrm{SL}$ & 80 & 0.94 & $0-111$ & 0.64 \\
\hline (c) & $87-1$ & DWT & $=-6.27+2.85 \mathrm{SL}$ & 148 & 0.96 & $2-81$ & 0.39 \\
\hline & $87-1$ & $\mathrm{ABD}$ & $=0.01+0.13 \mathrm{SL}$ & 150 & 0.76 & $2-81$ & $<0.001^{\circ}$ \\
\hline & $86-1,2$ & OTO & $=-0.73+1.00 \mathrm{SL}$ & 150 & 0.82 & $1-104$ & $0.007^{\circ}$ \\
\hline & $86-1,2$ & $\mathrm{ABD}$ & $=-0.16+0.16 \mathrm{SL}$ & 143 & 0.94 & $1-104$ & 0.25 \\
\hline & $86-2$ & DWT & $=-6.55+2.95 \mathrm{SL}$ & 158 & 0.98 & $-^{c}$ & \\
\hline & $86-2$ & $\mathrm{ABD}$ & $=-0.16+0.16 \mathrm{SL}$ & 441 & 0.95 & - & \\
\hline & $86-2$ & $\mathrm{DWT}^{\mathrm{b}}$ & $=-7.06+3.15 \mathrm{SL}$ & 124 & 0.98 & - & \\
\hline & $85-2$ & $A B D^{b}$ & $=-0.57+0.20 \mathrm{Si}$ & 181 & 0.97 & - & \\
\hline & $86-3$ & OTO & $=-0.73+0.79 \mathrm{SL}$ & 201 & 0.73 & $1-172$ & $<0.001^{\circ}$ \\
\hline & $86-3$ & $\mathrm{ABD}$ & $=-0.23+0.17 \mathrm{SL}$ & 194 & 0.97 & $1-172$ & 0.142 \\
\hline & $85-1,2$ & OTO & $=-1.41+0.98 \mathrm{SL}$ & 135 & 0.76 & $4-47$ & $0.002^{\circ}$ \\
\hline & $85-1,2$ & DWT & $=-6.89+3.06 \mathrm{SL}$ & 167 & 0.99 & $4-47$ & $0.01^{\bullet}$ \\
\hline & $85-1,2$ & $\mathrm{ABD}$ & $=-0.11+0.15 \mathrm{SL}$ & 220 & 0.94 & $4-47$ & 0.07 \\
\hline
\end{tabular}

The difference may be due to the larger larvae of this study having a greater proportion of TAG per unit DWT than smaller larvae, or other species. Cod pelagic juveniles have 2.6 times the amount of TAG per unit dry weight than capelin (Fraser unpubl.).

TAG may be an adequate condition index in other species that require lipid reserves for metamorphosis such as herring and bivalve larvae (Fraser 1989). Also, it is quite possible that because all of the cod in this study showed at least some growth, none were starving to the point of affecting TAG levels. Alternatively, Pedersen et al. (1989) showed that first-feeding cod larvae $(<10 \mathrm{~mm}$ length) had an initial decrease followed by an increase in TAG:cholesterol ratio, corresponding to changes in the dry weight condition index, and the food supply (calculated from their Table 1).

\section{Otolith indices}

The relationship between marginal increment widths and starvation/feeding events has been validated in the laboratory for larval and post-larval Atlantic menhaden, where reduced mean increment widths were observed after 1 to 3 d starvation (Maillet \& Checkley 1989). Atlantic cod larvae have not been laboratory-validated in such a manner as menhaden, although the otoliths of another gadoid, larval pollock ( $<7 \mathrm{~d}$ post-hatch), cease growth after 4 d of starvation (Bailey \& Stehr 1988). Bailey (1989) showed that the widths of the outer increments of juvenile pollock otoliths ( 50 to $60 \mathrm{~mm} \mathrm{SL}$ ) were also positively related to zooplankton biomass. Recent growth of the otolith in juvenile plajce has also been related to food abundance in the Wadden Sea (Karakiri et al. 1989). Similarly Hovenkamp (1990) found that larval plaice ( 9 to $13 \mathrm{~mm}$ SL), compared between cruises 2 wk apart, exhibited significant differences in the width of the outer 5 daily growth increments, and in RNA/ DNA ratios (though not of the same individual), which was considered to be due to food abundance.

\section{Correlation with zooplankton}

Zooplankton biomass was a significant covariate (after SL) for OTO on the 3 cruises $85-1,2,86-1,2$ and 

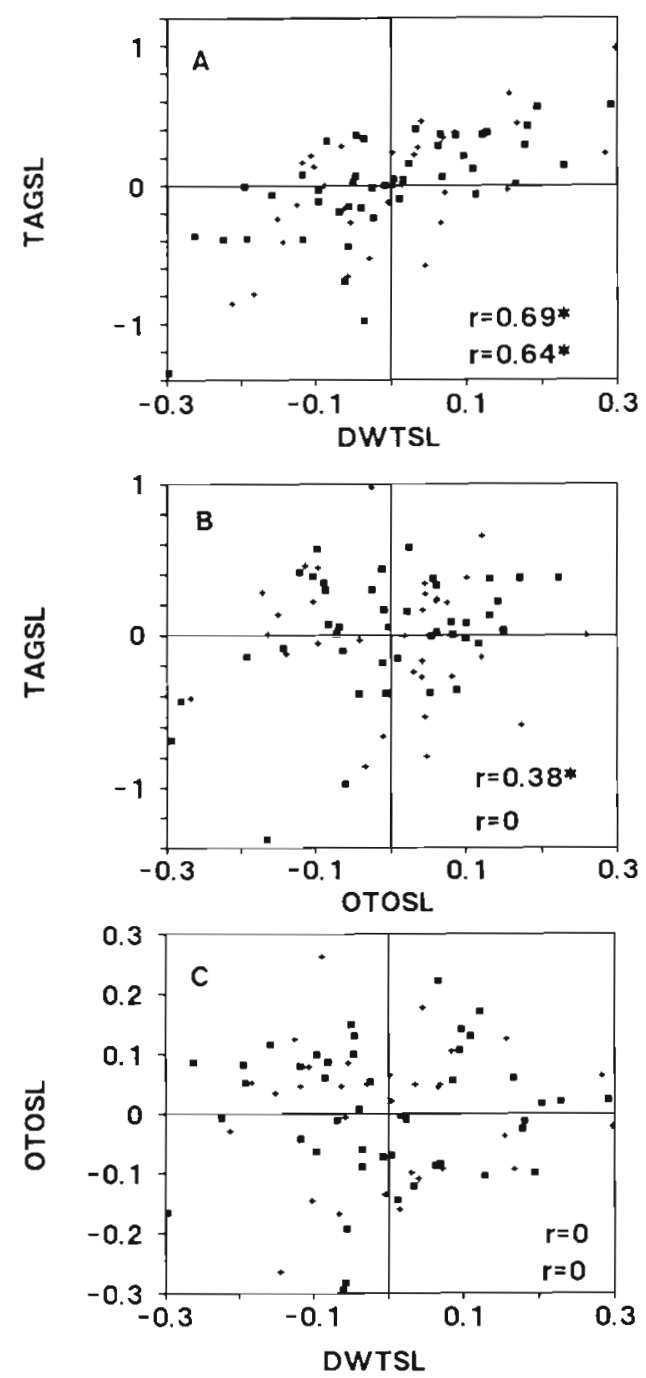

Fig. 4. Scatter-plots of (A) TAGSL on DWTSL, (B) TAGSL on OTOSL and (C) OTOSL on DWTSL. (•) Cruise $87-1 ;(\cdot)$ cruise 87-2. Upper correlation coefficients: cruise 87-1; lower coefficient: cruise $87-2$

86-3 (Suthers et al. 1989). On cruise 85-1,2 zooplankton was a significant covariate with DWT but was not a significant factor for ABD (although $\mathrm{p}=0.07$ ). The significant effect of zooplankton on cruise $87-1$ on TAG (Table 2a) was influenced by the very low zooplankton abundance and condition indices found nearshore (except OTO for unknown reasons). In the broad-scale survey of TAG on cruise 87-2 (Table 2b), there was no significant effect of zooplankton abundance (similar to ABD derived from fresh specimens). In sum, these field results confirm that the lipid and morphometric condition indices of pelagic juvenile cod are relatively insensitive to food levels, presumably as the individuals have reached a stage when they are able to integrate - or smooth out - small-scale variability in prey abundance. On the other hand, Koslow et al. (1985) found that DWT and $\mathrm{ABD}$ indices of post-larval cod were significantly
Table 3. Pearson correlation coefficients between residual indices derived from the same individual ( $\mathrm{p}<0.05$ )

\begin{tabular}{|c|c|c|c|}
\hline Cruise & Condition indices & $\mathrm{n}$ & $r$ \\
\hline $87-1$ & $\begin{array}{l}\text { TAGSL/DWTSL } \\
\text { DWTSL/OTOSL } \\
\text { OTOSL/TAGSL }\end{array}$ & $\begin{array}{l}41 \\
41 \\
41\end{array}$ & $\begin{array}{l}0.68^{\circ} \\
0.05^{\circ} \\
0.38^{\circ}\end{array}$ \\
\hline $87-2$ & $\begin{array}{l}\text { TAGSL/DWTSL } \\
\text { DWTSL/OTOSL } \\
\text { OTOSL/TAGSL }\end{array}$ & $\begin{array}{l}31 \\
31 \\
31\end{array}$ & $\begin{array}{c}0.64^{\circ} \\
0.03 \\
-0.05\end{array}$ \\
\hline $\begin{array}{l}87-1 \\
87-2\end{array}$ & $\begin{array}{l}\text { DWTSL/ABDSL } \\
\text { TAGSL/ABDSL }\end{array}$ & $\begin{array}{r}148 \\
80\end{array}$ & $\begin{array}{l}0.28^{\circ} \\
0.32^{\circ}\end{array}$ \\
\hline $\begin{array}{l}86-1 \\
86-2 \\
86-3\end{array}$ & $\begin{array}{l}\text { OTOSL/ABDSL } \\
\text { DWTSL/ABDSL } \\
\text { DWTSL/ABDSL } \\
\text { OTOSL/ABDSL }\end{array}$ & $\begin{array}{l}136 \\
158 \\
124 \\
176\end{array}$ & $\begin{array}{r}-0.06 \\
0.49^{\circ} \\
0.45^{\circ} \\
0.02\end{array}$ \\
\hline $85-1,2$ & $\begin{array}{l}\text { OTOSL/DWTSL } \\
\text { OTOSL/ABDSL } \\
\text { DWTSL/ABDSL }\end{array}$ & $\begin{array}{l}101 \\
101 \\
101\end{array}$ & $\begin{array}{l}0.19 \\
0.27^{\circ} \\
0.66^{\circ}\end{array}$ \\
\hline
\end{tabular}

correlated with total zooplankton biomass in southwestern Nova Scotia. As this study also made correlations over an order of magnitude in zooplankton biomass, the discrepancy may lie in comparing cod from a number of cruises over an extended period (February to June) in a single analysis, and confounding temperature with zooplankton abundance (which were highly correlated, $\mathrm{r}=0.56$; Table 4 of Koslow et al. 1985). Water temperature was not considered in our study due to the low range during each cruise over the survey area (Suthers et al. 1989).

\section{Influence of size and residual indices}

The response of an index to the environment may well differ when derived from a larva rather than from a pelagic juvenile. Our results suggest either that pelagic juveniles have an ability to withstand low food, or that the indices derived from large individuals are insensitive to nutritional stress. Ehrlich (1974) found that the resistance of larvae to starvation improved during ontogenesis. Powell \& Chester (1985) could distinguish fed and moderately starved pre-flexion larval spot, but could not do so for starved post-flexion larvae.

From a statistical viewpoint residual-based indices are satisfactory as size-independent measures of condition, providing that sub-groups of larvae have similar slopes when calculating the residual indices (e.g. Suthers et al. 1989). There were too few larvae on cruises $87-1$ and $87-2$ to test this possibility between the inshore and offshore subgroups. 
Table 4. Principal component loadings of (a) 5 variables on cruises $87-1$ and $87-2$, and (b) the first 5 components of 7 variables on cruise $85-1,2$

\begin{tabular}{|c|c|c|c|c|c|c|}
\hline Cruise & Variable & $\mathrm{PC} 1$ & PC2 & $\mathrm{PC} 3$ & $\mathrm{PC} 4$ & PC5 \\
\hline \multirow[t]{6}{*}{ (a) $87-1$} & CHOL & 0.97 & 0.16 & -0.03 & 0.15 & 0.10 \\
\hline & DWT & 0.97 & 0.21 & 0.04 & 0.06 & -0.13 \\
\hline & $\mathrm{SL}$ & 0.94 & 0.10 & 0.31 & -0.13 & 0.04 \\
\hline & TAG & 0.93 & 0.03 & -0.36 & -0.12 & 0.01 \\
\hline & OTO & 0.81 & -0.58 & 0.04 & 0.04 & -0.01 \\
\hline & Eigenvalue & $\begin{array}{l}4.26 \\
85 \%\end{array}$ & $\begin{array}{l}0.42 \\
8 \%\end{array}$ & $\begin{array}{l}0.23 \\
5 \%\end{array}$ & $\begin{array}{l}0.06 \\
1 \%\end{array}$ & $\begin{array}{l}0.03 \\
1 \%\end{array}$ \\
\hline \multirow[t]{6}{*}{$87-2$} & DWT & 0.99 & 0.08 & -0.08 & 0.08 & -0.05 \\
\hline & $\mathrm{CHOL}$ & 0.99 & 0.13 & 0.01 & 0.05 & 0.06 \\
\hline & $\mathrm{SL}$ & 0.98 & 0.02 & -0.19 & -0.09 & 0.0 \\
\hline & TAG & 0.96 & 0.21 & 0.20 & -0.05 & -0.02 \\
\hline & OTO & 0.87 & -0.50 & 0.07 & 0.0 & 0.0 \\
\hline & Eigenvalue & $\begin{array}{l}4.58 \\
92 \%\end{array}$ & $\begin{array}{l}0.31 \\
6 \%\end{array}$ & $\begin{array}{l}0.09 \\
2 \%\end{array}$ & $\begin{array}{l}0.02 \\
0 \%\end{array}$ & $\begin{array}{l}0.01 \\
0 \%\end{array}$ \\
\hline \multirow[t]{8}{*}{ (b) $85-1,2$} & DWT & 0.99 & 008 & -0.0 .3 & 0.04 & -0.07 \\
\hline & $\mathrm{SL}$ & 0.99 & 0.09 & 0.02 & 0.04 & -0.14 \\
\hline & PBD & 0.98 & 0.02 & -0.14 & -0.01 & 0.03 \\
\hline & $\mathrm{ABD}$ & 0.98 & 0.03 & -0.17 & 0.02 & 0.08 \\
\hline & $\mathrm{HL}$ & 0.96 & 0.10 & 0.18 & 0.15 & 0.09 \\
\hline & EYED & 0.96 & 0.17 & 0.10 & -0.22 & 0.03 \\
\hline & OTO & 0.83 & -0.55 & 0.05 & -0.03 & -0.0 \\
\hline & Eigenvalue & $\begin{array}{l}6.41 \\
92 \%\end{array}$ & $\begin{array}{l}0.36 \\
5 \%\end{array}$ & $\begin{array}{l}0.10 \\
1 \%\end{array}$ & $\begin{array}{l}0.07 \\
1 \%\end{array}$ & $\begin{array}{c}0.04 \\
1 \%\end{array}$ \\
\hline
\end{tabular}

\section{Principal component analysis}

Morphometric principal components are argued to be superior to residual indices, because residual indices are often correlated with other starvation-dependent variables, and thus contain further elements of shape (McGurk 1985a). However PC 2 and 3 were also highly correlated with OTO, and either TAG or ABD $(r=0.3$ to 0.6$)$, and were also correlated with the respective residual indices $(r>0.6)$. Therefore principal component analysis may not be appropriate for all multivariate condition analyses - particularly if there are different slopes for any subgroups of larvae. In this situation, the size component ( $\mathrm{PC}$ 1) could also remove information on shape.

The PC analyses revealed that after the size component was removed, OTO had the most remaining variation compared to TAG or ABD, while DWT (with $\mathrm{CHOL}$ ) had the least remaining variation. DWT was highly correlated with SL, with little residual variance, and therefore appears to be a less sensitive measure of condition in pelagic juveniles. This conclusion is supported by the similar slopes for DWT and ABD on SL between the inshore and offshore, or between cruises (in contrast to OTO). Similarly, Hovencamp (1990) showed significant differences in a biochemical condi- tion index of larval plaice between 2 cruises, but the relationship between $\ln (\mathrm{DWT})$ and $\ln (\mathrm{SL})$ was not significantly different [data contained in Table 6 of Hovenkamp (1990), ANCOVA $\mathrm{p}=0.9$ ]. DWT appears a particularly poor estimator of condition in pelagic juvenile cod.

\section{Conclusions}

The nutritional state of larval and pelagic juvenile fish may be confounded by other, unexamined processes. For example the effects of size on condition indices, and the effect of metabolic lags between a starvation/ feeding event and an index are unknown. The ability to discriminate declining and improving condition must be addressed, preferably using mesocosms to avoid laboratory artifacts. Validation of the peripheral increment width technique is required for the pelagic juvenile stage, but cod are difficult to raise to this size. Scoring histological sections of target tissues appears to be an important validation process, but time-consuming (Theilacker 1986, Martin \& Wright 1987), although the gut epithelium cell height appears to be a simple, robust index (Theilacker \& Watanabe 1989). This study has shown that caution is needed in applying a new 

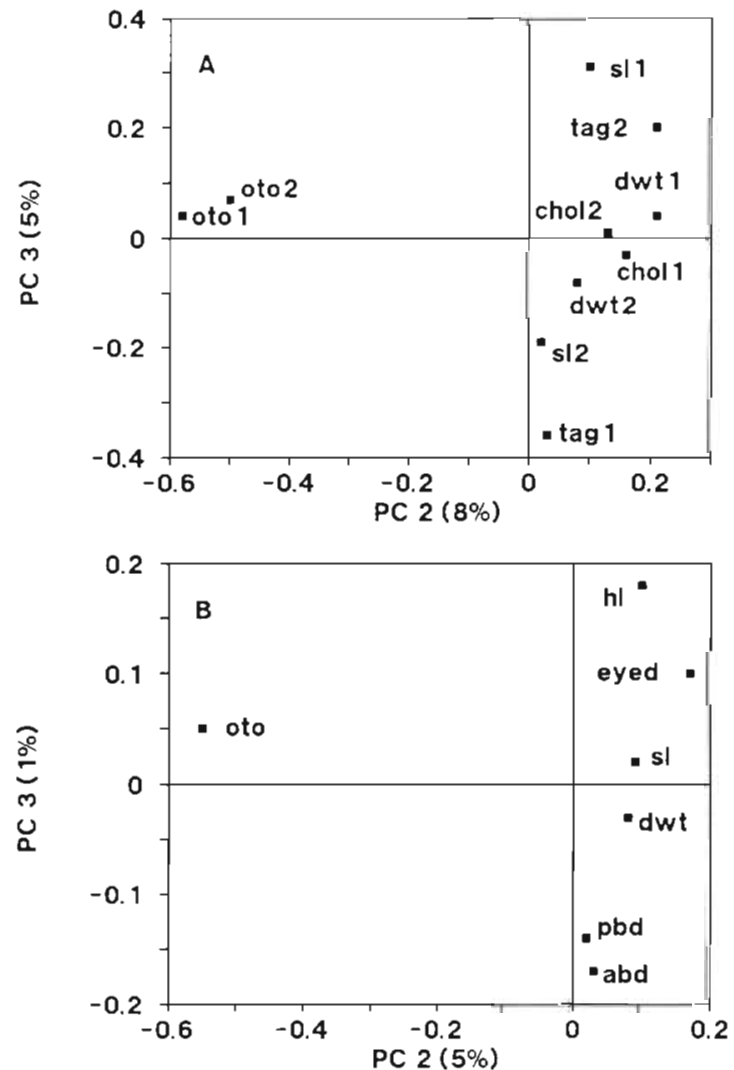

Fig. 5. Component loadings plots of each variable on the second and third principal components for (A) cruises 87-1 and $87-2$ and (B) cruise 85-1,2 abd: anal body depth; eyed: eye diameter; hl: head length; pbd: pectoral body depth; other abbreviations as in Figs. 1 \& 2

condition index (such as TAG), and in the type of analysis. Field sampling should be designed if possible to compare individuals between regions, depths or years using analysis of covariance. Biochemical indices are sometimes difficult to obtain at sea if the larvae are transparent and species-rich amongst the bulk of zooplankton, making rapid sorting before freezing difficult (Ehrlich et al. 1976). This study has confirmed that, if prior knowledge is lacking, 2 or more different indices should be generated - the choice depending on logistics, the biology of the species and on questions of interest (e.g. age distribution, and thus otolith microstructure). Otoliths are robust to routine handling and preservation in $95 \%$ ethanol (unlike morphometric and biochemical indices).

The effort to obtain both lipid, otolith and dry weight indices of condition is considerable, and an ideal index must be simple and size-independent, and integrate health of the previous few days. The importance of the pelagic juvenile stage in determining future recruitment (Sissenwine et al. 1984, Bjørke \& Sundby 1987), and the importance of food limitation at this stage
(Koslow et al. 1985, Peterman 1987, Bailey 1989, Karakiri et al. 1989, Suthers et al. 1989), highlights the need to assess pelagic juvenile health inter-annually and with regard to intra-annual distribution. Although we still know little about condition indices of pelagic juveniles and beyond, the low correlation between OTOSL and DWTSL in cod, and the significant relationship of OTOSL to zooplankton biomass, indicates that the width of the peripheral increments of the otolith is a powerful tool for estimating condition in pelagic juveniles.

Acknowledgements. We acknowledge the support from the crews of CSS 'Dawson', RV 'Prince' and RV 'Navicula', and in particular the technical help of Jeff McRuer and Peter Vass and the laboratory assistance of Randy Stone. This study was supported by a Killam pre-doctoral fellowship to I.M.S., the Natural Sciences and Engineering Council of Canada, and the Department of Fisheries and Oceans. We acknowledge the comments of P. Ouellet and Dr S. Campana.

\section{LITERATURE CITED}

Anderson, J. T (1988). A review of size dependent survival during pre-recruit stages of fishes in relation to recruitment. J. Northw. Atl. Sci. 8: 55-66

Bailey, K. M. (1989). Interaction between the vertical distribution of juvenile walleye pollock Theragra chalcogramma in the eastern Bering Sea, and cannibalism. Mar. Ecol. Prog. Ser 53: 205-213

Bailey, K. M., Stehr, C. L. (1988). The effects of feeding periodicity and ration on the rate of increment formation in otoliths of larval walleye pollock Theragra chalcogramma (Pallas). J. exp. mar. Biol. Ecol. 122: 147-161

Bjørke, H., Sundby, S. (1987). Distribution and abundance indices of postlarval and 0 -group cod. In: Loeng, H. (ed.) Proc. 3rd Soviet-Norwegian Symposium, Murmansk. The effect of oceanographic conditions on distribution and population dynamics of commercial fish stocks in the Barents Sea. Institute of Marine Research, Bergen, p. $127-144$

Blaxter, J. H. S. (1971). Feeding and condition of Clyde herring larvae. Rapp. P.-v. Réun. Cons. int. Explor Mer 160: 128-136

Buckley, L. J. (1984). RNA-DNA ratio: an index of larval fish growth in the sea. Mar. Biol. 80: 291-298

Buckley, L. J., Lough, R. G. (1987). Recent growth, biochemical composition, and prey field of larval haddock (Melanogrammus aeglefinus) and Atlantic cod (Gadus morhua) on Georges Bank. Can. J. Fish. Aquat. Sci. 44: 14-25

Campana, S. E. (1987). Image analysis for microscope-based observations: an inexpensive configuration. Can. Tech. Rep. Fish. Aquat. Sci. 1569: iv + 20pp.

Campana, S. E. (1990). How reliable are backcalculations based on otoliths? Can. J. Fish. Aquat. Sci. 47: 2219-2227

Chambers, C. R., Leggett, W. C., Brown, J. A. (1988). Variation in and among early life history traits of laboratory-reared winter flounder Pseudopleuronectes americanus. Mar Ecol. Prog. Ser. 47. 1-15

Ehrlich, K. F. (1974). Chemical changes during growth and starvation of larval Pleuronectes platessa. Mar Biol. 24: $39-48$

Ehrlich, K. F. (1975). A preliminary study of the chemical 
composition of sea-caught larval herring and plaice. Comp. Biochem. Physiol 51B: 25-28

Ehrlich, K. F., Blaxter, J. H. S., Pemberton, R. (1976). Morphological and histological changes during the growth and starvation of herring and plaice larvae. Mar Biol. 35: 105-118

Fahay, M. P. (1983). Guide to the early stages of marine fishes occurring in the western North Atlantic Ocean, Cape Hatteras to the Southern Scotian Shelf. J. Northw. Atl. Fish. Sci. $4: 423 \mathrm{p}$

Frank, K. T., McRuer, J. K. (1989). Nutritional status of fieldcollected haddock (Melanogrammus aeglefinus) larvae from southwestern Nova Scotia: an assessment based on morphometric and vertical distribution data. Can. J. Fish. Aquat. Sci. 46 (Suppl. 1): 125-133

Fraser, A. J. (1989). Triacylglycerol content as a condition index for fish, bivalve, and crustacean larvae. Can. J. Fish. Aquat. Sci. 46: 1868-1873

Fraser, A. J., Sargent, J. R., Gamble, J. C., MacLachlan, P. (1987). Lipid class and fatty acid composition as indicators of the nutritional condition of larval Atlantic herring. Am. Fish. Soc. Symp. 2: 129-143

Håkanson, J. L. (1989a). Analysis of lipid components tor determining the condition of anchovy larvae, Engraulis mordax. Mar. Biol. 102: 143-151

Håkanson, J. L. (1989b). Condition of larval anchovy (Engraulis mordax) in the Southern California Bight, as measured through lipid analysis. Mar. Biol. 1U2: 153-159

Hovenkamp, F. (1990). Growth differences in larval plaice Pleuronectes platessa in the southern Bight of the North Sea as indicated by otolith increments and RNA/DNA ratios. Mar. Ecol. Prog. Ser. 58: 205-215

Karakiri, M., Berghahn, R., von Westernhagen, H. (1989). Growth differences in 0 -group plaice Pleuronectes platessa as revealed by otolith microstructure analysis. Mar. Ecol. Prog. Ser. 55: 15-22

Koslow, J. A., Brault, S., Dugas, J., Fournier, R. O., Hughes, P. (1985). Condition of larval cod (Gadus morhua) off southwest Nova Scotia in 1983 in relation to plankton abundance and temperature. Mar. Biol. 86: 113-121

Maillet, G. L., Checkley, D. M. (1989). Effects of starvation on the frequency of formation and width of growth increments in sagittae of laboratory-reared Atlantic menhaden Brevoortia tyrannus larvae. Fish. Bull. U.S. 88: 155-165

Martin, F. D., Wright, D. A., Means, J. C. (1984). Fatty acids and starvation in larval striped bass (Morone saxatilis). Comp. Biochem. Physiol. 77B: 785-790

Martin, F. D., Wright, D. A. (1987). Nutritional state analysis and its use in predicting striped bass recruitment: laboratory calibration. Am. Fish. Soc. Symp. 2: 109-114

McGurk, M. D. (1985a). Multivariate analysis of morphometry and dry weight of Pacific herring larvae. Mar Biol. 86: $1-11$

McGurk, M. D. (1985b). Effects of net capture on the postpreservation morphometry, dry weight, and condition factor of Pacific herring larvae. Trans. Am. Fish. Soc. 114: 348-355

Methot, R. D. (1981). Spatial covariation of daily growth rates of larval northern anchovy, Engraulis mordax, and north-

This article was presented by $T$. Kiorboe, Charlottenlund, Denmark ern lampfish, Stenobrachius leucopsarus. Rapp. P.-v Réun. Cons. int. Explor. Mer 178: 424-431

O'Connell, C. P., Paloma, P. A. (1981). Histochemical indications of liver glycogen in samples of emaciated and robust larvae of the northern anchovy, Engraulis mordax. Fish. Bull. U.S. 78: 806-812

Pedersen, T., Eliassen, J. E., Eilertsen, H. C., Tande, K. S, Olsen, R. E. (1989). Feeding, growth, lipid composition, and survival of larval cod (Gadus morhua L.) in relation to environmental conditions in an enclosure at $70^{\circ}$ in northern Norway. Rapp. P.-v. Réun. Cons. int. Explor. Mer 191 $409-420$

Peterman, R. M. (1987). Review of the components of recruitment of Pacific salmon. Am. Fish. Soc. Symp. 1: 417-429

Powell, A. B., Chester, A. J. (1985). Morphometric indices of nutritional condition and sensitivity to starvation of spot larvae. Trans. Am. Fish. Soc. 114: 338-347

Sissenwine, M. P., Cohen, E. B., Grosslein, M. D. (1984). Structure of the Georges Bank ecosystem. Rapp. P.-v Réun. Cons, int. Explor. Mer 183: 243-254

Somers, K. M. (1986). Multivariate allometry and removal of size with principal components analysis. Syst. Zool. 35: $35 y-368$

Suthers, I. M.. Frank, K. T. (1989). Inter-annual distributions of larval and pelagic juvenile cod (Gadus morhua) in southwestern Nova Scotia determined with two different gear types. Can. J. Fish. Aquat. Sci. 46: 591-602

Suthers, i. ivl., Frank, h. T (1990). Zuuplankton biomass giadient off southwestern Nova Scotia; nearshore ctenophore predation, or hydrographic separation? J. Plankton Res. 12: $831-850$

Suthers, I. M., Frank, K. T., Campana, S. C. (1989). Spatial comparison of recent growth in post-larval cod (Gadus morhua) off southwestern Nova Scotia: inferior growth in a presumed nursery ared. Can. J. Fish. Aquat Sci. 46 (Suppl. 1): $13-124$

Taggart, C. T., Leggett, W. C. (1987a). Short-term mortality in post-emergent larval capelin Mallotus villosus. I. Analysis of multiple in situ estimates. Mar Ecol. Prog. Ser 41. 205-217

Taggart, C. T., Leggett, W. C. (1987b). Short-term mortality in post-emergent larval capelin Mallotus villosus. II. Importance of food and predator density, and density-dependence. Mar. Ecol. Prog. Ser. 41: 219-229

Theilacker, G. H. (1978). Effect of starvation on the histological and morphological characteristics of jack mackerel Trachurus symmetricus larvae. Fish. Bull. U.S. 76: 403-414

Theilacker, G. H. (1980). Changes in body measurements of larval northern anchovy, Engraulis mordax, and other fishes tue to handling and preservation. Fish. Bull. U.S. 78: $685-692$

Theilacker, G. H. (1986). Starvation-induced mortality of young sea-caught jack mackerel, Trachurus symmetricus, determined with histological and morphological methods. Fish. Bull. U.S. 84: 1-17.

Theilacker, G. H., Watanabe, Y (1989). Midgut cell height defines nutritional status of laboratory raised larval northern anchovy, Engraulis mordax. Fish. BulI. U.S. 87 $457-469$

Manuscript first received: September 9, 1991

Revised version accepted: May 8, 1992 


\title{
Reproduction of the deep-water shrimp Aristeus antennatus (Decapoda: Dendrobranchiata)
}

\author{
Montserrat Demestre, José-Manuel Fortuño
}

Institut de Ciències del Mar, Passeig Nacional s/n, E-08039 Barcelona, Spain

\begin{abstract}
Morphology, structure, and function of the reproductive system of the shrimp Aristeus antennatus (Risso, 1816) were investigated using light microscopy and scanning electron microscopy. Monthly samples were taken by trawling on the continental slope $(400$ to $800 \mathrm{~m})$ of the northwestern Mediterranean during 1984, 1985, 1986 and 1989. Sexual characteristics, thelycum, petasma, genital apertures, appendix masculina, and rostrum were considered and possible functions in reproductive behaviour are suggested. The roles of testis, proximal and medial vas deferens regions, and terminal ampulla in hemispermatophore formation were assessed. During mating hemispermatophores join and form a compound spermatophore. The sperm mass in the compound spermatophore was surrounded by 5 layers secreted along the vas deferens duct. Open-type thelycum species with external mating and fertilization such as $A$. antennatus need to develop a complex spermatophore to protect the sperm mass. The structure of sperm was examined for the first time in A. antennatus. The peculiar morphological features of this immobile sperm differ considerably from sperm cells of other decapod groups. It is suggested that this spermatophore formation and sperm structure have taxonomic and phylogenetic value. Spermatogenesis and spermatophore formation divided male gonad development and functionality into 3 stages. Oagenesis can be divided into 6 stages taking into consideration cytological changes in the oocytes. A key to macroscopically identify sexual stages of gonad development which can be used externally on fresh or live specimens is proposed based on the study of gametogenesis and gonad and sexual characteristic development and function.
\end{abstract}

\section{INTRODUCTION}

There is a great deal of experimental scientific literature on commercial coastal species of the suborder Dendrobranchiata due to its importance in aquaculture. Many studies have been made on aspects of artificial feeding, force-feeding and on induction of spawning (Dall et a]. 1990) but little is known of the reproductive biology of these shrimps in the field environment, and even less when dealing with deepwater species, with Mediterranean species being the least known of all (Dall 1991). The 'gamba shrimp' Aristeus antennatus (Risso, 1816) is an exploited species which plays an important role in the overall biomas of the muddy bottoms of the slope 1400 to $2000 \mathrm{~m}$ ) in the Northwestern Mediterranean (Cartes \& Sardà 1989, Demestre 1990).

An initial general description of the secondary sexual characteristics and development of genitalia in both sexes of Aristeus antennatus was given by Heldt (1938). Subsequent studies have increased knowledge on reproduction of this species (Relini Orsi \& Relini 1979, Arrobas \& Ribeiro Cascalho 1987, Orsi Relini \& Tunesi 1987, Sardà \& Demestre 1987, Demestre 1990). However, many aspects of its reproductive biology are still largely unknown, as is the case with many other exploited species, in spite of this being indispensable information for subsequent assessment and management studies of its fishery

The main objective of this study was thus to achieve a thorough understanding of the biology and dynamics of reproduction in this species. Different processes related to changes in the structure, morphology and functionality of the reproductive system, in both females and males, of Aristeus antennatus were studied throughout the maturation process. For the first time, a scanning electron microscopy image of its sperm is presented. Detailed study of ovary development and 